\title{
Exploring the activity of chemical-activated carbons synthesized from peach stones as metal-free catalysts for wet peroxide oxidation
}

\author{
Maria Martin-Martinez ${ }^{\mathrm{a}}$, Silvia Álvarez-Torrellas ${ }^{\mathrm{b}}$, Juan García ${ }^{\mathrm{b}}$, Adrián M.T. Silva ${ }^{\mathrm{c}}$, \\ Joaquim L. Faria ${ }^{c}$, Helder T. Gomes ${ }^{\mathrm{a}, *}$

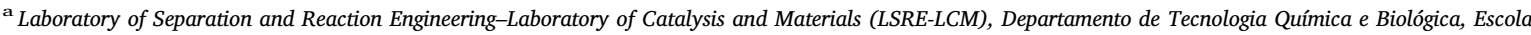 \\ Superior de Tecnologia e Gestão, Instituto Politécnico de Bragança, Campus de Santa Apolónia, 5300-253 Bragança, Portugal \\ ${ }^{\mathrm{b}}$ Grupo de Catálisis y Procesos de Separación (CyPS), Departamento de Ingeniería Química, Facultad de Ciencias Químicas, Universidad Complutense de Madrid, Avda. \\ Complutense $s / n, 28040$ Madrid, Spain \\ ${ }^{\mathrm{c}}$ Laboratory of Separation and Reaction Engineering-Laboratory of Catalysis and Materials (LSRE-LCM), Departamento de Engenharia Química, Faculdade de \\ Engenharia, Universidade do Porto, Rua Dr. Roberto Frias s/n, 4200-465 Porto, Portugal
}

\section{A R T I C L E I N F O}

\section{Keywords:}

Peach stone

Chemical activation

Activated carbon

Metal-free CWPO

\begin{abstract}
A B S T R A C T
Peach stones were used as raw material for the synthesis of activated carbons with different properties. Firstly, peach stones were chemically activated using a $12 \mathrm{M} \mathrm{H}_{3} \mathrm{PO}_{4}$ solution and carbonized under flowing air $\left(400{ }^{\circ} \mathrm{C}\right.$ ). The obtained activated carbon, named as PS, is characterized by a high surface development $\left(\mathrm{S}_{\mathrm{BET}}=1262 \mathrm{~m}^{2} \mathrm{~g}^{-1}\right)$ and acidic character $\left(\mathrm{pH}_{\mathrm{PZC}}=4.2\right)$. A fraction of PS was further carbonized under $\mathrm{N}_{2}$ atmosphere at $800{ }^{\circ} \mathrm{C}$ to remove surface functionalities and to increase its basicity (PS-800). In addition, a Pt catalyst supported on PS ( $3 \% \mathrm{w} / \mathrm{w}$ Pt/PS) was synthesized by incipient wetness impregnation, resulting in a considerable hydrophilicity increasing. The synthesized materials were tested in the catalytic wet peroxide oxidation (CWPO) of highly concentrated solutions of 4-nitrophenol (4-NP, $5 \mathrm{~g} \mathrm{~L}^{-1}$ ) during $24 \mathrm{~h}$ experiments, conducted at relatively mild operating conditions $\left(\mathrm{T}=50-110^{\circ} \mathrm{C}, \mathrm{pH}=3\right.$, catalyst load $=2.5 \mathrm{gL}^{-1}$ and $\left[\mathrm{H}_{2} \mathrm{O}_{2}\right]_{0}=17.8 \mathrm{~g} \mathrm{~L}^{-1}$, corresponding to the stoichiometric amount of $\mathrm{H}_{2} \mathrm{O}_{2}$ needed for the complete mineralization of 4-NP). It was observed that the increase of electron-donating functionalities in PS-800 promotes the generation of reactive $\mathrm{HO}$ - radicals, being the activity towards CWPO twice higher than that obtained with the pristine PS. Besides, increasing operating temperature substantially enhances CWPO, finding a 80\% of 4-NP removal at $110^{\circ} \mathrm{C}$. On the other hand, despite the sharp increment in $\mathrm{H}_{2} \mathrm{O}_{2}$ decomposition due to the presence of Pt particles in Pt/PS catalyst, this decomposition is inefficient in all cases, with a consequent poor pollutant removal. This can be attributed to the recombination of $\mathrm{HO} \cdot$ radicals into non-reactive species - scavenging effects, promoted by the hydrophilicity of the catalyst.
\end{abstract}

\section{Introduction}

Catalytic wet peroxide oxidation (CWPO) relies on the oxidation of organic species using hydrogen peroxide $\left(\mathrm{H}_{2} \mathrm{O}_{2}\right)$ and a suitable catalyst to promote the formation of $\mathrm{HO}$ - radicals, under relatively mild operation conditions $\left(0.1-0.2 \mathrm{MPa}, 20-130^{\circ} \mathrm{C}\right)[1,2]$.

The classical heterogeneous catalysts employed in CWPO process consist on an active phase, mainly a transition metal like Fe, supported on a porous material, like activated carbon. However, metal leaching of the metallic phase to the reaction medium is usual with these catalysts, leading to a severe deactivation [3-6]. This has led to the exploration of metal-free materials capable to catalyze the decomposition of $\mathrm{H}_{2} \mathrm{O}_{2}$ [7-10]. In this context, due to their electron donor-acceptor surface properties, activated carbons have been used as catalysts in CWPO [10-15] since they allow $\mathrm{H}_{2} \mathrm{O}_{2}$ decomposition into $\mathrm{HO}^{\circ}$ radicals in a similar mechanism than the Fenton process, according to the following scheme, where $\mathrm{AC}$ and $\mathrm{AC}^{+}$represents, respectively, reduced and oxidized active sites existing at the surface of activated carbons:

$\mathrm{AC}+\mathrm{H}_{2} \mathrm{O}_{2} \rightarrow \mathrm{AC}^{+}+\mathrm{HO} \cdot+\mathrm{OH}^{-}$

$\mathrm{AC}^{+}+\mathrm{H}_{2} \mathrm{O}_{2} \rightarrow \mathrm{AC}+\mathrm{HOO} \cdot+\mathrm{H}^{+}$

The use of metal-free carbonaceous materials as catalysts has become important in recent years, constituting $c a .30 \%$ of the publications regarding the CWPO process (Web of Science). Nevertheless, among these studies, the pollutant oxidation is, in general, moderate, low

\footnotetext{
* Corresponding author.

E-mail address: htgomes@ipb.pt (H.T. Gomes).
} 
activities being obtained for the removal of phenolic compounds [13-17], even when using doses of $\mathrm{H}_{2} \mathrm{O}_{2}$ higher than the stoichiometric. Besides, the removal of organic pollutants using these catalysts proceeds mostly through pollutant adsorption [1,12,15,17-22]. On the other hand, radical recombination is common in these studies, affecting the efficient consumption of $\mathrm{H}_{2} \mathrm{O}_{2}$ into $\mathrm{HO}$ - radicals, since non-reactive species like $\mathrm{H}_{2} \mathrm{O}$ and $\mathrm{O}_{2}$ are formed [23].

Different authors have tried to improve the properties of activated carbons for CWPO through chemical modification of their surface [11-14,16,24], since basic groups enhance $\mathrm{H}_{2} \mathrm{O}_{2}$ decomposition and acid groups withdraw electrons from the carbon surface, hindering their use in $\mathrm{H}_{2} \mathrm{O}_{2}$ attack, which may result in the restriction of secondary reactions like radicals recombination [8,12-15,24-28].

The analysis of the scientific literature reveals that activated carbons have been synthesized through both, physical and chemical activation methods, from different lignocellulosic residues, like wood, bamboo, sawdust, nuts, cherry stones, peach stones, rice husk, almond shells, peanut shells, potato peels or coffee wastes, among others, with good mechanical and porous properties [29-31]. In this study, peach stones are used as raw material for the synthesis of activated carbons with different surface properties, evaluating their performance as catalysts in the CWPO of wastewaters with high pollutant concentration. A 4-nitrophenol (4-NP, $5 \mathrm{~g} \mathrm{~L}^{-1}$ ) model solution was used to mimic highly polluted wastewaters.

\section{Materials and methods}

\subsection{Chemicals}

Peach stones were collected from a local agricultural company (Madrid, Spain) producing peach syrup. 4-NP (98 wt.\%) was purchased from Acros Organics. $\mathrm{H}_{2} \mathrm{O}_{2}(30 \%$, w/v) was obtained from Fluka. Sodium hydroxide (NaOH, 98 wt.\%) was acquired from Panreac. Acetic acid (glacial acetic acid), acetonitrile and methanol (all HPLC grade, 99.99 wt.\%) were purchased from Fisher Chemical. Hydrochloric acid ( $\mathrm{HCl}, 37 \mathrm{wt} . \%$ ), titanium (IV) oxysulphate (15 wt.\% in dilute sulphuric acid, $99.99 \%)$, sodium sulphite $\left(\mathrm{Na}_{2} \mathrm{SO}_{3}, 98 \mathrm{wt} . \%\right)$, phosphoric acid (85 wt.\%) and $\mathrm{H}_{2} \mathrm{PtCl}_{6}$ were obtained from Sigma-Aldrich. All chemicals were used as received without further purification. Ultrapure water was used throughout the work.

\subsection{Synthesis of carbon materials}

An activated carbon was prepared by chemical activation of peach stones (previously crushed and sieved to a particle size between 0.5 and $1.0 \mathrm{~mm}$ ), in a round-bottom flask reactor, using a $\mathrm{H}_{3} \mathrm{PO}_{4}$ solution $\left(12 \mathrm{~mol} \mathrm{~L}^{-1}\right)$ as activating agent, at $85^{\circ} \mathrm{C}$ for $6 \mathrm{~h}$, in a mixture of $200 \mathrm{~g} \mathrm{~L}^{-1}$. After impregnation, the solid was filtered and calcined during $4 \mathrm{~h}$ in a vertical quartz reactor under air flow $\left(50 \mathrm{~cm}^{3} \mathrm{~min}^{-1}\right)$ at $400{ }^{\circ} \mathrm{C}$, defining a heating ramp of $5^{\circ} \mathrm{C} \mathrm{min}^{-1}$. The resulting carbon was thoroughly washed with ultrapure water to remove the remaining phosphoric acid, until a pH close to neutrality was reached. Finally, the solid was dried in an oven at $110^{\circ} \mathrm{C}$ for $24 \mathrm{~h}$. The resulting carbon, ground to particle sizes in the range $100-250 \mu \mathrm{m}$, was named as PS. As it will be shown in the Results and Discussion Section, this material presents acid character. In order to improve its catalytic properties for wet peroxide oxidation process, two strategies have been followed. On the one hand, a fraction of PS was further calcined under $\mathrm{N}_{2}$ atmosphere $\left(100 \mathrm{~cm}^{3} \mathrm{~min}^{-1}\right)$ for $4 \mathrm{~h}$ at $800{ }^{\circ} \mathrm{C}$, to remove surface functionalities, increasing the basicity of the carbon. This material was named as PS-800. On the other hand, a metallic Pt catalyst supported on PS was synthesized by incipient wetness impregnation method, using a $\mathrm{H}_{2} \mathrm{PtCl}_{6}$ aqueous solution of the required concentration to obtain $3 \% \mathrm{w} /$ $\mathrm{w}$ active phase nominal loading in the catalyst. After drying at $110^{\circ} \mathrm{C}$ overnight, the activation of the catalyst was carried out by reduction under $\mathrm{N}_{2}: \mathrm{H}_{2}\left(150: 50 \mathrm{~cm}^{3} \mathrm{~min}^{-1}\right)$ continuous flow at $350{ }^{\circ} \mathrm{C}$ for $3 \mathrm{~h}$. This catalyst was named as Pt/PS.

\subsection{Characterization}

Elemental analyses were performed on a LECO CHNS-932 analyzer. Bulk Pt content was determined using X-ray fluorescence (XRF, S4 Explorer, Bruker).

Pt dispersion on the catalyst surface was determined by $\mathrm{CO}$ chemisorption at room temperature (PulseChemiSorb 2705, Micromeritics). The stoichiometry of the $\mathrm{CO}$ adsorption on the metallic atoms was assumed to be 1 .

X-ray diffraction (XRD) patterns were obtained in a X'Pert-MPD diffractometer (PANalytical), using $\mathrm{Cu} \mathrm{K \alpha}$ monochromatic radiation $(0.154056 \mathrm{~nm})$, a scanning range of $5-100^{\circ}$ and a scan step size of $0.1^{\circ}$ with $1 \mathrm{~s}$ collection time.

The porous structure of the catalysts was characterized by $\mathrm{N}_{2}$ adsorption-desorption isotherms at $-196{ }^{\circ} \mathrm{C}$ and $\mathrm{CO}_{2}$ adsorption-desorption isotherms at $0^{\circ} \mathrm{C}$ (Tristar II 3020, Micromeritics). The samples were previously outgassed for $12 \mathrm{~h}$ at $150{ }^{\circ} \mathrm{C}$ at a residual pressure of $10^{-3}$ Torr (VacPrep 061, Micromeritics). The specific surface area $\left(\mathrm{S}_{\mathrm{BET}}\right)$ was calculated by BET equation. The micropore surface area $\left(\mathrm{S}_{\text {micro }}\right)$, mesopore surface area $\left(\mathrm{S}_{\text {meso }}\right)$ and micropore volume $\left(\mathrm{V}_{\text {micro }}\right)$ were estimated by the $t$-plot method and the mesopore volume $\left(\mathrm{V}_{\text {meso }}\right)$ was determined by subtracting $\mathrm{V}_{\text {micro }}$ value from the total $\mathrm{N}_{2}$ amount adsorbed at $\mathrm{P} / \mathrm{P}_{0}=0.95[32-34]$. The pore size distribution of the materials was obtained by using the Non-Local Density Functional Theory [35].

The $\mathrm{pH}$ of point of zero charge $\left(\mathrm{pH}_{\mathrm{PZC}}\right)$ was determined by $\mathrm{pH}$ drift tests adapting the procedure described elsewhere [36]. Five $\mathrm{NaCl}$ $(0.01 \mathrm{M})$ solutions were prepared as electrolyte with varying initial $\mathrm{pH}$, in the range 2-11 (using $\mathrm{HCl}$ and $\mathrm{NaOH} 0.1 \mathrm{M}$ solutions). $0.05 \mathrm{~g}$ of carbon sample was contacted with $20 \mathrm{~mL}$ of each $\mathrm{NaCl}$ solution. The equilibrium $\mathrm{pH}$ of each suspension was measured after $48 \mathrm{~h}$ under stirring $(200 \mathrm{rpm})$ in an orbital shaker at room temperature. The $\mathrm{pH}_{\mathrm{PZC}}$ value was determined by intercepting the curve 'final $\mathrm{pH} v s$ initial $\mathrm{pH}$ ' with the main diagonal of the plot (final $\mathrm{pH}=$ initial $\mathrm{pH}$ ) [37].

Temperature programmed desorption (TPD) analyses were performed by heating $0.1 \mathrm{~g}$ of the carbon sample from $25^{\circ} \mathrm{C}$ up to $1100^{\circ} \mathrm{C}$ $\left(5^{\circ} \mathrm{C} \mathrm{min}{ }^{-1}\right)$, in a quartz tube reactor, under constant $\mathrm{N}_{2}$ flow $\left(1000 \mathrm{~cm}^{3} \mathrm{~min}^{-1}\right)$. The evolving concentrations of $\mathrm{CO}$ and $\mathrm{CO}_{2}$ were monitored using a SIEMENS Ultramat 22 gas analyzer. The peaks deconvolution of the TPD profiles were adjusted to multiple Gaussian functions by Origin Pro 9.0 software, according to the literature [38].

Fourier Transform Infrared Spectroscopy (FT-IR) was performed in a Thermo Nicolet spectrophotometer, recording spectra in a wavelength range of $400-4600 \mathrm{~cm}^{-1}$.

\subsection{4-Nitrophenol removal experiments}

The CWPO runs were carried out in a batch reaction system described elsewhere [23], consisting of a $250 \mathrm{~mL}$ glass reactor with a sample collection port, magnetically stirred (600 rpm), immersed in an oil bath with temperature control and equipped with a reflux condenser. In a typical experiment, the reactor was loaded with $50 \mathrm{~mL}$ of a highly concentrated 4-NP aqueous solution $\left(5 \mathrm{~g} \mathrm{~L}^{-1}\right)$ and heated up to the desired temperature $\left(50{ }^{\circ} \mathrm{C}\right.$ or $\left.80^{\circ} \mathrm{C}\right)$. Initial $\mathrm{pH}$ was adjusted to 3 using $\mathrm{H}_{2} \mathrm{SO}_{4}$ and $\mathrm{NaOH} 0.1 \mathrm{M}$ solutions, and the stoichiometric concentration of $\mathrm{H}_{2} \mathrm{O}_{2}$ needed to mineralize completely 4-NP was added to the system $\left(17.8 \mathrm{~g} \mathrm{~L}^{-1}\right)$. The reaction started with the addition of $2.5 \mathrm{~g} \mathrm{~L}^{-1}$ of catalyst. During the experiment, small aliquots were periodically withdrawn from the reactor, typically at $0,5,15,30,60,120$, 240, 480 and $1440 \mathrm{~min}$, for analysis. A blank experiment, i.e. without catalyst, was carried out to assess possible non-catalytic oxidation reactions promoted by $\mathrm{H}_{2} \mathrm{O}_{2}$.

A set of experiments was carried out at higher temperature $\left(110^{\circ} \mathrm{C}\right)$, using a stoppered $500 \mathrm{~mL}$ glass batch reactor (Büchi), equipped with a backpressure controller. First, the reactor was loaded with $150 \mathrm{~mL}$ of $5 \mathrm{~g} \mathrm{~L}^{-1} 4$-NP aqueous solution at $\mathrm{pH} 3$ and $2.5 \mathrm{~g} \mathrm{~L}^{-1}$ of catalyst. Once 
the desired temperature was reached, the stoichiometric concentration of $\mathrm{H}_{2} \mathrm{O}_{2}$ was incorporated, starting the reaction.

On the other hand, the adsorption capacity of the different synthesized materials was evaluated by means of pure adsorption experiments, in which a volume of distilled water was added to the system in substitution of $\mathrm{H}_{2} \mathrm{O}_{2}$.

The experiments were performed by triplicate, the standard deviation being lower than $5 \%$ in all cases.

\subsection{Analytical methods}

4-NP was identified and quantified as described elsewhere [23], by means of a Jasco HPLC system, with an UV-Vis detector (UV-2075 Plus), adjusting the absorbance wavelength to $318 \mathrm{~nm}$. The system incorporates a quaternary gradient pump (PU-2089 Plus) for solvent delivery and a Kromasil 100-5-C18 column $(15 \mathrm{~cm} \times 4.6 \mathrm{~mm}$; $5 \mu \mathrm{m}$ particle size) working at room temperature. Before the sample analysis, in order to stop the reaction, an excess of $\mathrm{Na}_{2} \mathrm{SO}_{3}$ was added to consume the residual $\mathrm{H}_{2} \mathrm{O}_{2}[11,39]$ and the catalyst was removed by filtration. The mobile phase $\left(1 \mathrm{~mL} \mathrm{~min}^{-1}\right)$ consisted of $3 \%$ acetic acid and $1 \%$ acetonitrile in methanol (A) and 3\% acetic acid in ultrapure water (B), working in isocratic mode A:B (40:60, v/v).

The concentration of $\mathrm{H}_{2} \mathrm{O}_{2}$ in solution was determined by a colorimetric method using an UV/Vis spectrophotometer (T70 Spectrometer, $P G$ Instruments Ltd.). The filtered sample was acidified with a $\mathrm{H}_{2} \mathrm{SO}_{4}$ $0.5 \mathrm{M}$ solution. Then, $0.1 \mathrm{~mL}$ of titanium oxysulfate was added, and the absorbance was measured at $405 \mathrm{~nm}$ [40].

Finally, the total organic carbon (TOC) content was determined using a Shimadzu TOC-L analyzer.

\section{Results and discussion}

\subsection{Characterization results}

The elemental composition and bulk platinum content of the carbonaceous materials are given in Table 1 . The presence of oxygen is very important in PS, but the release of volatile matter during its calcination causes a significant reduction of oxygen in the calcined PS-800 material. The decrease of the $\mathrm{O} / \mathrm{C}$ ratio in PS- 800 is indicative of the lower polarity of the calcined carbon [41]. Regarding to the catalyst Pt/ PS, the XRF analysis confirmed that the measured Pt content lies close to the nominal value calculated from the amount of the used precursor.

The CO chemisorption analysis of Pt/PS (Table 1) indicates that the metallic phase is fairly well-dispersed, pointing to platinum particles sizes of about $6 \mathrm{~nm}[42,43]$. This may be due to the acidity properties of the support, since the presence of acidic groups increases the hydrophilic character of the support, favoring the diffusion of the platinum precursor, facilitating the metal dispersion $[44,45]$. Nevertheless, the XRD profile of the catalyst (Fig. 1) showed four peaks at $2 \theta=39.8$, $46.3,67.5$ and $81.3^{\circ}$, typical of a face centered cubic lattice of platinum, indicating the presence of large platinum particles too.

According to IUPAC classification, the $\mathrm{N}_{2}$ adsorption-desorption isotherms at $-196^{\circ} \mathrm{C}$ of the materials (Fig. S1, Supplementary Material) approaches Type 1, typical of microporous solids, with a $\mathrm{H} 4$ hysteresis cycle due to the contribution of mesopores. The textural properties of the materials are summarized in Table 1, and the

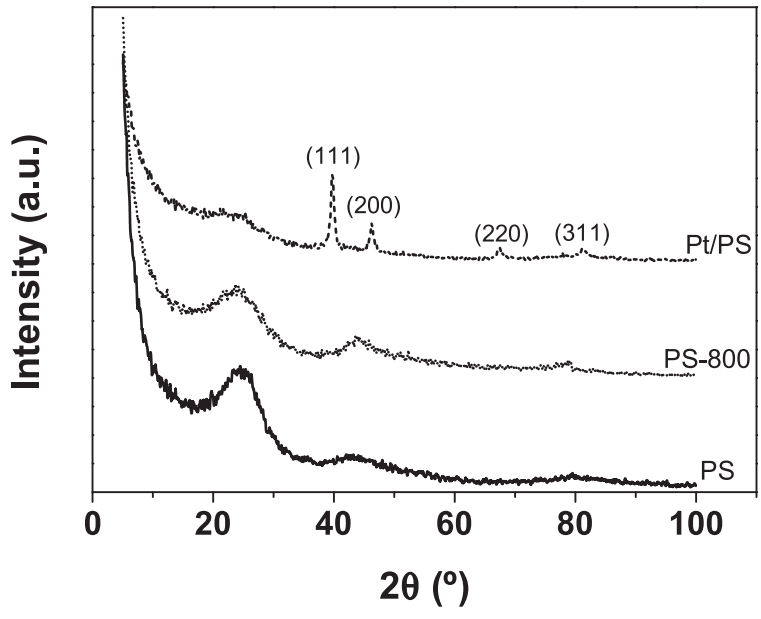

Fig. 1. XRD patterns of the tested carbon materials.

micropore size distribution can be found in the Supplementary Material (Fig. S2). PS revealed a high BET surface area value (ca. $1260 \mathrm{~m}^{2} \mathrm{~g}^{-1}$ ), with important contribution of both, micropores and mesopores. The calcined material also presented a highly developed porosity $\left(\mathrm{S}_{\mathrm{BET}} \approx 1050 \mathrm{~m}^{2} \mathrm{~g}^{-1}\right)$, even though the calcination treatment substantially degenerates its carbonaceous structure, possibly due to partial gasification [46]. The incorporation of the active phase in Pt/PS catalyst did not modify significantly the textural properties of the support, which remained basically unchanged.

Regarding to the surface chemistry of the materials, $\mathrm{pH}_{\mathrm{PZC}}$ values (Table 1) revealed the acidic character of PS and Pt/PS catalysts, whilst the calcined PS-800 carbon showed a $\mathrm{pH}_{\mathrm{PZC}}$ value set at neutrality. These results are in accordance to the oxygen content of PS-800 carbon observed by elemental analysis, since surface oxygenated-functionalities may have been removed during the thermal treatment. Additionally, these observations are consistent to TPD results and FT-IR spectra, as it will be discussed below.

Table 2 shows the amount of the surface functional groups present in the synthesized materials, quantified by the deconvolution of the TPD profiles (Fig. S3, Supplementary Material) according to the procedure described elsewhere [38]. Briefly, $\mathrm{CO}_{2}$ profile can be deconvoluted into carboxylic acids (peaks in the range $270-350{ }^{\circ} \mathrm{C}$ ), carboxylic anhydrides $\left(440-590^{\circ} \mathrm{C}\right.$ ) and lactones $\left(620-710^{\circ} \mathrm{C}\right)$, and the $\mathrm{CO}$ profile represents the sum of carboxylic anhydrides $\left(440-590{ }^{\circ} \mathrm{C}\right)$, phenols $\left(620-680^{\circ} \mathrm{C}\right)$, ethers $\left(740-770^{\circ} \mathrm{C}\right)$ and carbonyls/quinones $\left(850-900^{\circ} \mathrm{C}\right.$ ). The acidic character of PS carbon can be understood due to the large concentration of carboxylic and phenolic surface functionalities. The signal associated to carbonyls/quinones may be mainly caused by carbonyl groups, according to previous $\mathrm{pH}_{\mathrm{PZC}}$ results. It is noteworthy the decrease in the proportion of acidic groups in PS-800 carbon, while the concentration of quinones increased instead, consistent with the variation in $\mathrm{pH}_{\mathrm{PZC}}$. The $\mathrm{pH}_{\mathrm{PZC}}$ value in $\mathrm{Pt} / \mathrm{PS}$ catalyst also points to the fundamental contribution of carbonyls to the signal associated to carbonyl/quinone, being acidic lactones, anhydrides and phenols, and the neutral ethers and carbonyls, the main functional groups found in Pt/PS material. The presence of these functional groups is also confirmed by FT-IR spectra, where bands associated to

Table 1

Composition (\% w/w), textural properties, Pt dispersion (D) and $\mathrm{pH}_{\mathrm{PZC}}$ of the tested carbon materials.

\begin{tabular}{|c|c|c|c|c|c|c|c|c|c|c|c|c|c|c|}
\hline & C (\%) & $\mathrm{O}^{\mathrm{a}}(\%)$ & H (\%) & N (\%) & S (\%) & $\mathrm{O} / \mathrm{C}$ & Pt (\%) & D (\%) & $\mathrm{S}_{\mathrm{BET}}\left(\mathrm{m}^{2} \mathrm{~g}^{-1}\right)$ & $S_{\text {micro }}\left(m^{2} g^{-1}\right)$ & $S_{\text {meso }}\left(m^{2} g^{-1}\right)$ & $\mathrm{V}_{\text {micro }}\left(\mathrm{cm}^{3} \mathrm{~g}^{-1}\right)$ & $\mathrm{V}_{\text {meso }}\left(\mathrm{cm}^{3} \mathrm{~g}^{-1}\right)$ & $\mathrm{pH}_{\mathrm{PZC}}$ \\
\hline PS & 68.70 & 27.04 & 3.91 & 0.33 & 0.02 & 0.39 & - & - & 1262 & 938 & 324 & 0.45 & 0.112 & 4.2 \\
\hline PS-800 & 86.31 & 12.20 & 1.24 & 0.23 & 0.02 & 0.14 & - & - & 1045 & 787 & 257 & 0.39 & 0.071 & 7.1 \\
\hline $\mathrm{Pt} / \mathrm{PS}$ & 80.71 & 16.04 & 2.87 & 0.37 & 0.01 & 0.20 & 2.84 & 17 & 1231 & 827 & 404 & 0.41 & 0.091 & 3.8 \\
\hline
\end{tabular}

a difference to $100 \%$. 
Table 2

Surface oxygenated functionalities of the tested carbon materials by TPD analyses.

\begin{tabular}{|c|c|c|c|c|c|c|c|c|}
\hline & $\mathrm{CO}_{2}\left(\mu \mathrm{molg}^{-1}\right)$ & $\mathrm{CO}\left(\mu \mathrm{mol} \mathrm{g}{ }^{-1}\right)$ & $\begin{array}{l}\text { carboxylic } \\
\left(\mu \mathrm{mol} g^{-1}\right)\end{array}$ & $\begin{array}{l}\text { lactone } \\
\left(\mu \mathrm{mol} \mathrm{g}^{-1}\right)\end{array}$ & $\begin{array}{l}\text { anhydride } \\
\left(\mu \mathrm{mol} g^{-1}\right)\end{array}$ & $\begin{array}{l}\text { phenol } \\
\left(\mu \mathrm{mol} g^{-1}\right)\end{array}$ & ether $\left(\mu \mathrm{mol} \mathrm{g}{ }^{-1}\right)$ & $\begin{array}{l}\text { carbonyl/ quinone } \\
\left(\mu \mathrm{mol} \mathrm{g}{ }^{-1}\right)\end{array}$ \\
\hline PS & 633 & 2982 & 138 & 6 & 87 & 266 & 852 & 1764 \\
\hline PS- 800 & 375 & 1635 & 35 & 32 & 56 & 64 & 324 & 1949 \\
\hline $\mathrm{Pt} / \mathrm{PS}$ & 312 & 2260 & 6 & 181 & 77 & 67 & 665 & 1773 \\
\hline
\end{tabular}

carboxylic acids and carbonyls, quinones and lactones were observed in PS, PS-800 and Pt/PS materials, respectively (Fig. S4, Supplementary Material).

\subsection{Catalytic performance in CWPO experiments}

The synthesized materials were used as catalysts in the CWPO of highly concentrated 4-NP solutions. Catalytic activity may depend on both textural and surface chemical properties of the carbons. The role played by the porosity of the carbon materials in the decomposition of $\mathrm{H}_{2} \mathrm{O}_{2}$ seems to be related with the disorder in their structure: the higher the microporosity and surface concentration of available electrons, the higher the catalyst activity in the decomposition of $\mathrm{H}_{2} \mathrm{O}_{2}$ [25]. On the other hand, the important role of the surface acid/basic properties of the carbon in the catalytic decomposition of $\mathrm{H}_{2} \mathrm{O}_{2}$ is well known. As it was explained in the Introduction Section, several authors have documented that basic carbon materials lead to higher $\mathrm{H}_{2} \mathrm{O}_{2}$ decomposition rates, whilst acid materials present a limited activity in the decomposition of $\mathrm{H}_{2} \mathrm{O}_{2}$. Besides, Ribeiro et al. [8] reported that the presence of basic functionalities in the carbon materials increased the yield of $\mathrm{HO}$ - formation during the decomposition of $\mathrm{H}_{2} \mathrm{O}_{2}$.

Fig. 2 shows the evolution of 4-NP and $\mathrm{H}_{2} \mathrm{O}_{2}$ concentrations in $24 \mathrm{~h}$ CWPO reactions for each catalyst. The adsorption contribution to the removal of 4-NP (not shown) was marginal in all cases, probably due to the fast catalyst surface saturation caused by the high pollutant concentration used in the experiments $\left(5 \mathrm{~g} \mathrm{~L}^{-1}\right)$. Since the textural properties of the materials under study are quite similar, the different catalytic activity shown may be mainly explained by their different surface chemical properties. As it can be observed, the activated carbon PS showed poor catalytic activity. The presence of surface acidic groups in PS suppressed the dissociation of $\mathrm{H}_{2} \mathrm{O}_{2}$, hindering its decomposition. Besides, traces of residual phosphates from the synthesis of PS with $\mathrm{H}_{3} \mathrm{PO}_{4}$ may increase the inhibiting action of the decomposition of $\mathrm{H}_{2} \mathrm{O}_{2}$ [26], which reached only to $5 \%$ when the reaction was carried out at $50{ }^{\circ} \mathrm{C}$. Even though this value increased when operating at higher temperatures $\left(80^{\circ} \mathrm{C}\right.$ and $110{ }^{\circ} \mathrm{C}$ ), ca. only $30 \%$ of $\mathrm{H}_{2} \mathrm{O}_{2}$ was decomposed in the best scenario. Consequently, the removal of 4-NP by CWPO with PS is limited.

Comparing with PS, the decomposition of $\mathrm{H}_{2} \mathrm{O}_{2}$ increased slightly but significantly by using PS- 800 catalyst. As it was shown in the characterization analyses, the thermal treatment at $800^{\circ} \mathrm{C}$ resulted in the removal of the surface acidic groups, increasing the number of basic functionalities instead, promoting the generation of $\mathrm{HO} \cdot$ radicals along the reaction. This resulted in the significant removal of 4-NP, being the activity towards CWPO twice higher when compared to that observed with the original PS. The catalytic activity becomes substantially higher when increasing the operating temperature from $50{ }^{\circ} \mathrm{C}$ to $110{ }^{\circ} \mathrm{C}$ (Table 3). At the highest tested temperature, ca. $80 \%$ of pollutant concentration was removed after $24 \mathrm{~h}$. Several studies can be found in the scientific literature regarding to the removal of 4-NP by CWPO with metal-free catalysts (Table 4). Fathy et al. [47] reported complete 4-NP removal using a phosphorous-doped porous carbon xerogel. But they treated low concentrated 4-NP aqueous solutions $(50 \mathrm{mg} / \mathrm{L})$, using a higher reaction temperature $\left(90^{\circ} \mathrm{C}\right)$. Besides, they reported $20 \%$ 4-NP removal due to adsorption, which is not marginal. Rodrigues et al. [48] found an even higher adsorption contribution (45\%) during the

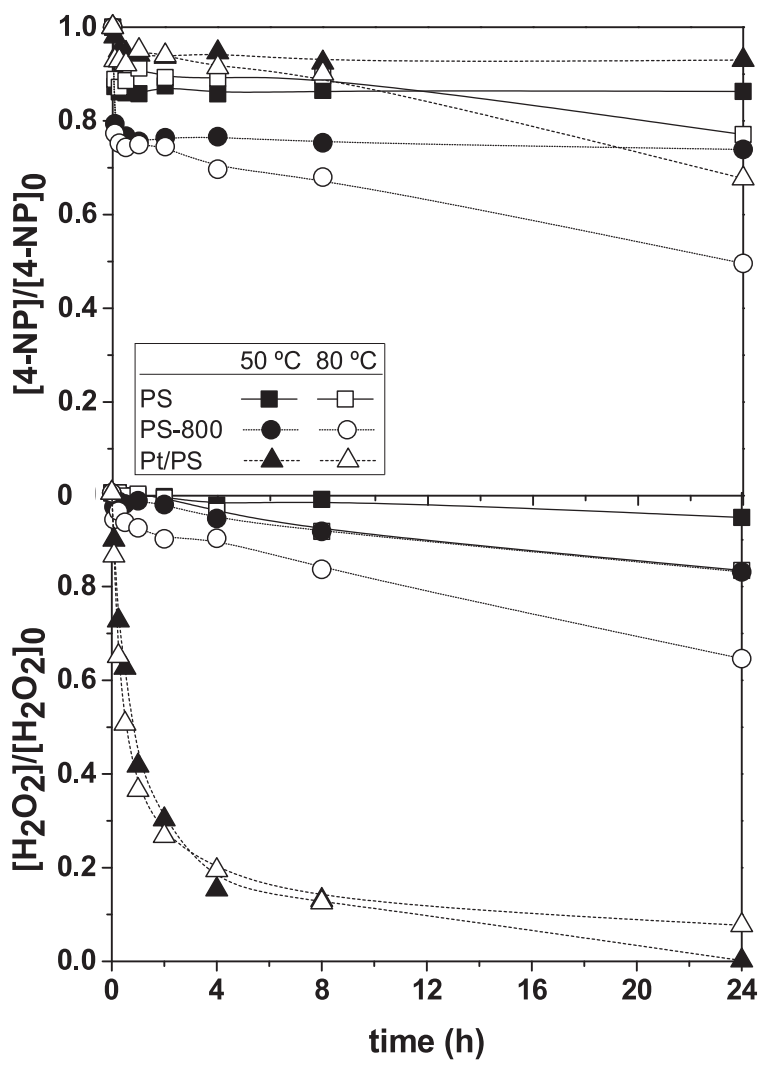

Fig. 2. Concentration evolution with time for 4-NP and $\mathrm{H}_{2} \mathrm{O}_{2}$ during the CWPO experiments with the tested carbon materials. Operating conditions: $C_{4-N P}=5 \mathrm{~g} \mathrm{~L}^{-1}$, $C_{\mathrm{H}_{2} \mathrm{O}_{2}}=17.8 \mathrm{~g} \mathrm{~L}^{-1}, C_{\text {cat }}=2.5 \mathrm{~g} \mathrm{~L}^{-1}, \mathrm{pH}=3$.

Table 3

Removal of 4-NP by adsorption (Ads.) and CWPO $\left(\mathrm{X}_{4-\mathrm{NP}}\right)$; and TOC removal $\left(\mathrm{X}_{\mathrm{TOC}}\right), \mathrm{H}_{2} \mathrm{O}_{2}$ decomposition $\left(\mathrm{X}_{\mathrm{H}_{2} \mathrm{O}_{2}}\right)$ and $\eta_{\mathrm{H}_{2} \mathrm{O}_{2}}$.

\begin{tabular}{lllllll}
\hline & $\mathrm{T}\left({ }^{\circ} \mathrm{C}\right)$ & Ads. (\%) & $\mathrm{X}_{4-\mathrm{NP}}(\%)$ & $\mathrm{X}_{\mathrm{H}_{2} \mathrm{O}_{2}}(\%)$ & $\mathrm{X}_{\mathrm{TOC}}(\%)$ & $\eta_{\mathrm{H}_{2} \mathrm{O}_{2}}$ \\
\hline \multirow{2}{*}{ PS } & 50 & 8 & 14 & 5 & 4 & 80 \\
& 80 & 6 & 23 & 17 & 14 & 82 \\
& 110 & 5 & 35 & 31 & 26 & 83 \\
PS-800 & 50 & 11 & 26 & 17 & 16 & 94 \\
& 80 & 9 & 50 & 35 & 32 & 91 \\
& 110 & 7 & 78 & 65 & 56 & 86 \\
Pt/PS & 50 & 3 & 7 & 100 & 19 & 19 \\
& 80 & 2 & 32 & 95 & 29 & 31 \\
\hline
\end{tabular}

treatment of solutions with higher concentration of 4-NP $(500 \mathrm{mg} / \mathrm{L})$, using N-doped activated carbon as catalyst. These authors removed $60 \%$ of pollutant by CWPO working at $30{ }^{\circ} \mathrm{C}$. Other studies present complete 4-NP removal by CWPO in the treatment of $100 \mathrm{mg} / \mathrm{L}$ [49] and $200 \mathrm{mg} / \mathrm{L}$ [50] 4-NP solutions, using nitric acid activated fly ash and hybrid magnetic graphitic nanocomposites, respectively, but no information about adsorption contribution was described. Increasing 4$\mathrm{NP}$ concentration to $5000 \mathrm{mg} / \mathrm{L}$, the same concentration used in the present work, lower contributions of adsorption were reported, probably due to the catalyst surface saturation caused by the high pollutant 
Table 4

Results of 4-NP removal by CWPO and adsorption by metal-free catalysts in literature.

\begin{tabular}{|c|c|c|c|c|c|}
\hline Catalyst & $\begin{array}{l}\text { Adsorption } \\
\text { removal (\%) }\end{array}$ & $\begin{array}{l}\text { CWPO } \\
\text { removal } \\
(\%)\end{array}$ & $\begin{array}{l}{[4-} \\
\mathrm{NP}]_{0} \\
(\mathrm{mg} / \mathrm{L})\end{array}$ & $\mathrm{T}\left({ }^{\circ} \mathrm{C}\right)$ & Reference \\
\hline Fly-ash & - & 98 & 100 & 25 & [49] \\
\hline $\begin{array}{l}\text { Reduced graphene } \\
\quad \text { oxide }\end{array}$ & 5 & 65 & 5000 & 50 & [51] \\
\hline $\begin{array}{l}\text { P-doped carbon } \\
\text { xerogels }\end{array}$ & 20 & 100 & 50 & 90 & [47] \\
\hline CNT & 7 & 100 & 5000 & 50 & [23] \\
\hline Lignin-based AC & 5 & 66 & 5000 & 50 & {$[52]$} \\
\hline $\begin{array}{l}\text { Magnetic graphitic } \\
\text { nanocomposites }\end{array}$ & - & 100 & 200 & 80 & {$[50]$} \\
\hline Melamine-doped AC & 45 & 60 & 500 & 30 & [48] \\
\hline
\end{tabular}

concentration. Similar results were reported by Ribeiro et al. [51] and Martin-Martinez et al. [52]: A 65\% 4-NP removal by CWPO and 5\% contribution due to adsorption, when using reduced graphene oxide and lignin-based activated carbon, respectively, at $50^{\circ} \mathrm{C}$. Moreover, in a recent work [23], complete 4-NP removal was obtained by CWPO of highly loaded solutions $(5000 \mathrm{mg} / \mathrm{L})$ at $50^{\circ} \mathrm{C}$, using carbon nanotubes as catalyst. As observed in other studies with high pollutant concentration, the adsorption contribution to 4-NP removal was not high (7\%), maybe due to the catalyst surface saturation.

The presence of a metallic active phase in Pt/PS dramatically increased the decomposition of $\mathrm{H}_{2} \mathrm{O}_{2}$. Pt particles increased the material hydrophilicity; consequently, the catalyst strongly attracted polar molecules like $\mathrm{H}_{2} \mathrm{O}_{2}$. This effect can be qualitatively observed in the dispersion tests carried out in toluene/water biphasic systems (see Fig. S5, Supplementary Material). The stronger affinity of the metal-free materials for the toluene phase was clearly observed, while the Pt-containing catalyst is mainly located at the toluene/water interface (since it is composed by a hydrophobic support and hydrophilic metal particles). Liu et al. [53] found that under acidic conditions, the decomposition of $\mathrm{H}_{2} \mathrm{O}_{2}$ catalyzed by Pt nanoparticles runs according to a peroxidase-like catalyzed mechanism, resulting in the formation of $\mathrm{HO}^{\circ}$ radicals. In a recent publication, it was demonstrated that highly hydrophilic surfaces promoted the total decomposition of $\mathrm{H}_{2} \mathrm{O}_{2}$ into non-reactive species $\left(\mathrm{H}_{2} \mathrm{O}\right.$ and $\left.\mathrm{O}_{2}\right)$, due to the recombination of radicals [23]. Therefore, during the CWPO runs with Pt/PS catalyst, $\mathrm{H}_{2} \mathrm{O}_{2}$ molecules may be quickly attracted by the catalyst hydrophilic surface and decomposed into $\mathrm{HO}^{\circ}$ radicals, following a peroxidase-like mechanism. Due to the strong competition with $\mathrm{H}_{2} \mathrm{O}_{2}$ molecules, 4-NP molecules may have difficulties to reach the surface of the catalyst and to be attacked by the radicals. As a consequence, radicals recombine between themselves into non-reactive $\mathrm{H}_{2} \mathrm{O}$ and $\mathrm{O}_{2}$ and a poor pollutant removal was obtained. The fast Pt-catalyzed selective decomposition of $\mathrm{H}_{2} \mathrm{O}_{2}$ into non-reactive species has been reported before in the literature [54-56]. Hydrophilic Pt particles catalyze the decomposition of $\mathrm{H}_{2} \mathrm{O}_{2}$, decreasing the activation energy and increasing the decomposition rate. Since working at even higher temperature would increment the kinetic of $\mathrm{H}_{2} \mathrm{O}_{2}$ decomposition into $\mathrm{HO}$ - radicals in the earlier stages of the reaction, this contribute to the described inefficient mechanism, so experiments at higher temperatures were not performed with $\mathrm{Pt} / \mathrm{PS}$.

Related to the TOC removal, Table 3 shows that, in all cases, the obtained mineralization level tends to increase with operation temperature. The acid activated carbon PS converted only $26 \%$ of the initial TOC content after $24 \mathrm{~h}$ working at the highest temperature $\left(110^{\circ} \mathrm{C}\right)$. This is due to the poor decomposition of $\mathrm{H}_{2} \mathrm{O}_{2}$ reached with this material. Nevertheless, it resulted in a highly effective posterior radical's attack to the pollutant molecules $(\eta \approx 80 \%)$. The opposite behavior was observed for the catalyst Pt/PS. As it was explained above, despite the high decomposition of $\mathrm{H}_{2} \mathrm{O}_{2}$ achieved, the frustrate approximation of the 4-NP molecules to the catalyst surface impede their oxidation and mineralization $\left(\mathrm{X}_{\mathrm{TOC}} \approx 30 \%\right.$ at the highest temperature), being the efficiency of $\mathrm{H}_{2} \mathrm{O}_{2}$ significantly low. Finally, a high efficiency of $\mathrm{H}_{2} \mathrm{O}_{2}$ when using the calcined PS-800 material was obtained $(\eta \approx 90 \%)$, being able to remove $56 \%$ of TOC at the highest tested temperature.

\section{Conclusions}

The chemical surface properties of the carbonaceous materials play an important role in the CWPO of 4-NP since they strongly affect the mechanism of $\mathrm{H}_{2} \mathrm{O}_{2}$ decomposition. The presence of surface acidic groups in PS carbon hinders the decomposition of $\mathrm{H}_{2} \mathrm{O}_{2}(31 \%$ at $110^{\circ} \mathrm{C}$ ). The impregnation of the carbon with platinum strongly favors $\mathrm{H}_{2} \mathrm{O}_{2}$ decomposition, which is complete after $24 \mathrm{~h}$ at $50{ }^{\circ} \mathrm{C}$, but the consequent high hydrophilicity of the catalyst promoted the formation of non-reactive $\mathrm{H}_{2} \mathrm{O}$ and $\mathrm{O}_{2}$ species, impeding the oxidation of the pollutant. The increase of electron-donating functionalities in PS-800 carbon led the generation of reactive $\mathrm{HO}$ - radicals, which effectively attack the pollutant molecules $\left(\eta_{\mathrm{H}_{2} \mathrm{O}_{2}} \approx 90 \%\right)$, being the activity towards CWPO twice than that observed with the pristine PS. Thus, in this case, $80 \%$ of $4-\mathrm{NP}$ was removed after $24 \mathrm{~h}$ at $110^{\circ} \mathrm{C}$.

\section{Acknowledgments}

This work is a result of project “AIProcMat@N2020 - Advanced Industrial Processes and Materials for a Sustainable Northern Region of Portugal 2020", with the reference NORTE-01-0145-FEDER-000006, supported by NORTE 2020, under the Portugal 2020 Partnership Agreement, through the ERDF and of Project POCI-01-0145-FEDER006984-Associate Laboratory LSRE-LCM funded by ERDF through COMPETE2020 - POCI - and by national funds through FCT. M. Martín Martínez and A.M.T. Silva acknowledge the FCT Postdoc grant SFRH/BPD/108510/2015 and FCT Investigator 2013 Programme IF/ 01501/2013, respectively.

\section{Appendix A. Supplementary data}

Supplementary data associated with this article can be found, in the online version, at https://doi.org/10.1016/j.cattod.2018.01.003.

\section{References}

[1] S. Navalon, A. Dhakshinamoorthy, M. Alvaro, H. Garcia, ChemSusChem 4 (2011) 1712-1730.

[2] C.W. Jones, Applications of Hydrogen Peroxide and Derivatives, Royal Society of Chemistry, 1999.

[3] E.V. Rokhina, J. Virkutyte, Crit. Rev. Environ. Sci. Technol. 41 (2011) 125-167.

[4] G. Calleja, J.A. Melero, F. Martinez, R. Molina, Water Res. 39 (2005) 1741-1750.

[5] A. Rey, M. Faraldos, J.A. Casas, J.A. Zazo, A. Bahamonde, J.J. Rodriguez, Appl. Catal. B-Environ. 86 (2009) 69-77.

[6] A. Onda, Y. Suzuki, S. Takemasa, K. Kajiyoshi, K. Yanagisawa, J. Mater. Sci. 43 (2008) 4230-4235.

[7] L. Liu, Y. Zhu, M. Su, Z. Yuan, ChemCatChem 7 (2015) 2765-2787.

[8] R.S. Ribeiro, A.M.T. Silva, J.L. Figueiredo, J.L. Faria, H.T. Gomes, Carbon 62 (2013) 97-108.

[9] R.S. Ribeiro, A.M.T. Silva, M.T. Pinho, J.L. Figueiredo, J.L. Faria, H.T. Gomes, Catal. Today 240 (2015) 61-66.

[10] C.M. Domínguez, P. Ocón, A. Quintanilla, J.A. Casas, J.J. Rodriguez, Appl. Catal. BEnviron. 140-141 (2013) 663-670.

[11] F. Duarte, F.J. Maldonado-Hódar, L.M. Madeira, Appl. Catal. B-Environ. 103 (2011) 109-115.

[12] L.C.A. Oliveira, C.N. Silva, M.I. Yoshida, R.M. Lago, Carbon 42 (2004) 2279-2284.

[13] H.T. Gomes, S.M. Miranda, M.J. Sampaio, A.M.T. Silva, J.L. Faria, Catal. Today 151 (2010) 153-158.

[14] H. Huang, M. Lu, J. Chen, C. Lee, Chemosphere 51 (2003) 935-943.

[15] A. Rey, M. Faraldos, A. Bahamonde, J.A. Casas, J.A. Zazo, J.J. Rodriguez, Ind. Eng. Chem. Res. 47 (2008) 8166-8174.

[16] R.S. Ribeiro, A.M.T. Silva, J.L. Figueiredo, J.L. Faria, H.T. Gomes, Appl. Catal. BEnviron. 140-141 (2013) 356-362.

[17] J.A. Zazo, J.A. Casas, A.F. Mohedano, J.J. Rodríguez, Appl. Catal. B-Environ. 65 (2006) 261-268.

[18] A. Dhaouadi, N. Adhoum, Appl. Catal. B-Environ. 97 (2010) 227-235.

[19] M. Soria-Sánchez, E. Castillejos-López, A. Maroto-Valiente, M.F.R. Pereira, J.J.M. Órfão, A. Guerrero-Ruiz, Appl. Catal. B-Environ. 121-122 (2012) 182-189.

[20] O.P. Pestunova, O.L. Ogorodnikova, V.N. Parmon, Chem. Sus. Devel. 11 (2003) 
$227-232$.

[21] L. Gu, N. Zhu, H. Guo, S. Huang, Z. Lou, H. Yuan, J. Hazard. Mater. 246 (2013) 145-153.

[22] O. Türgay, G. Ersöz, S. Atalay, J. Forss, U. Welander, Sep. Purif. Techn. 79 (2011) 26-33.

[23] M. Martin-Martinez, R.S. Ribeiro, B.F. Machado, P. Serp, S. Morales-Torres, A.M.T. Silva, J.L. Figueiredo, J.L. Faria, H.T. Gomes, ChemCatChem 8 (2016) 2068-2078.

[24] V.P. Santos, M.F.R. Pereira, P.C.C. Faria, J.J.M. Órfão, J. Hazard. Mater. 162 (2009) $736-742$.

[25] A. Rey, J.A. Zazo, J.A. Casas, A. Bahamonde, J.J. Rodriguez, Appl. Catal. A-Gen. 402 (2011) 146-155.

[26] L.B. Khalil, B.S. Girgis, T.A. Tawfik, J. Chem. Technol. Biot. 76 (2001) 1132-1140.

[27] O. Taran, E. Polyanskaya, O. Ogorodnikova, V. Kuznetsov, V. Parmon, M. Besson, C. Descorme, Appl. Catal. A-Gen. 387 (2010) 55-66.

[28] F. Lücking, H. Köser, M. Jank, A. Ritter, Water Res. 32 (1998) 2607-2614.

[29] D. Duranoğlu, A.W. Trochimczuk, Ü. Beker, Chem. Eng. J. 165 (2010) 56-63.

[30] S. Álvarez-Torrellas, M. Martin-Martinez, H.T. Gomes, G. Ovejero, J. García, Appl. Surf. Sci. 414 (2017) 424-434.

[31] J.V. Flores-Cano, M. Sánchez-Polo, J. Messoud, I. Velo-Gala, R. Ocampo-Pérez, J. Rivera-Utrilla, J. Environ. Manage. 169 (2016) 116-125.

[32] S. Brunauer, P.H. Emmett, E. Teller, J. Am. Chem. Soc. 60 (1938) 309-319.

[33] G. Halsey, J. Chem. Phys. 16 (1948) 931-937.

[34] B.C. Lippens, B.G. Linsen, J.H. de Boer, J. Catal. 3 (1964) 32-37.

[35] J. Jagiello, M. Thommes, Carbon 42-47 (2004) 1227-1232.

[36] G. Newcombe, R. Hayes, M. Drikas, Colloid Surf. A 78 (1993) 65-71.

[37] J.J.M. Órfão, A.I.M. Silva, J.C.V. Pereira, S.A. Barata, I.M. Fonseca, P.C.C. Faria, M.F.R. Pereira, J. Colloid Interf. Sci. 296 (2006) 480-489.

[38] J.L. Figueiredo, M.F.R. Pereira, M.M.A. Freitas, J.J.M. Órfão, Carbon 37 (1999) 1379-1389.

[39] J.H. Ramirez, C.A. Costa, L.M. Madeira, G. Mata, M.A. Vicente, M.L. Rojas-
Cervantes, A.J. López-Peinado, R.M. Martín-Aranda, Appl. Catal. B-Environ. 71 (2007) 44-56.

[40] W.C. Ketchie, Y. Fang, M.S. Wong, M. Murayama, R.J. Davis, J. Catal. 250 (2007) 94-101.

[41] G. Oh, Y. Ju, M. Kim, H. Jung, H.J. Kim, W. Lee, Sci. Total Environ. 393 (2008) 341-347.

[42] J. Freel, J. Catal. 25 (1972) 139-148.

[43] J. Freel, J. Catal. 25 (1972) 149-160.

[44] L. Calvo, M.A. Gilarranz, J.A. Casas, A.F. Mohedano, J.J. Rodriguez, Ind. Eng. Chem. Res. 44 (2005) 6661-6667.

[45] J. Bedia, J.M. Rosas, J. Rodríguez-Mirasol, T. Cordero, Appl. Catal. B-Environ. 94 (2010) 8-18.

[46] C. Moreno-Castilla, M. Ferro-Garcia, J.P. Joly, I. Bautista-Toledo, F. Carrasco-Marin, J. Rivera-Utrilla, Langmuir 11 (1995) 4386-4392.

[47] N.A. Fathy, M.A. Shouman, R.M.M. Aboelenin, Asia-Pac. J. Chem. Eng. 11 (2016) $836-845$.

[48] C.S.D. Rodrigues, O.S.G.P. Soares, M.T. Pinho, M.F.R. Pereira, L.M. Madeira, Appl. Catal. B-Environ. 219 (2017) 109-122.

[49] A. Zhang, N. Wang, J. Zhou, P. Jiang, G. Liu, J. Hazard. Mater. 201 (2012) 68-73.

[50] R.S. Ribeiro, A.M.T. Silva, P.B. Tavares, J.L. Figueiredo, J.L. Faria, H.T. Gomes, Catal. Today 280 (2017) 184-191.

[51] R.S. Ribeiro, A.M.T. Silva, L.M. Pastrana, J.L. Figueiredo, J.L. Faria, H.T. Gomes, Catal. Today 249 (2015) 204-212.

[52] M. Martin-Martinez, M.F.F. Barreiro, A.M.T. Silva, J.L. Figueiredo, J.L. Faria, H.T. Gomes, Appl. Catal. B-Environ. 219 (2017) 372-378.

[53] Y. Liu, H. Wu, M. Li, J. Yin, Z. Nie, Nanoscale 6 (2014) 11904-11910.

[54] G. Blanco-Brieva, M.P. de Frutos-Escrig, H. Martin, J.M. Campos-Martin, J.L.G. Fierro, Catal. Today 187 (2012) 168-172.

[55] K.M. Marr, B. Chen, E.J. Mootz, J. Geder, M. Pruessner, B.J. Melde, R.R. Vanfleet, I.L. Medintz, B.D. Iverson, J.C. Claussen, ACS Nano 9 (2015) 7791-9803.

[56] R. Javaid, U.Y. Qazi, S.I. Kawasaki, Bull. Chem. Soc. Jpn. 88-7 (2015) 976-980. 